\title{
Potentials of E-learning as a Study Tool in Business Education in Nigerian Schools
}

\author{
Ojeaga, I. J. ${ }^{1} \&$ Igbinedion, V. I. ${ }^{1}$ \\ ${ }^{1}$ Department of Vocational and Technical Education, Faculty of Education, University of Benin, Benin \\ Correspondence: Igbinedion, V. I., Department of Vocational and Technical Education, Faculty of Education, \\ University of Benin, Benin. Tel: 229-805-601-4291. E-mail: vicidion@gmail.com
}

Received: May 11, 2012 Accepted: June 13, 2012 Online Published: September 16, 2012

doi:10.5539/ies.v5n5p218 URL: http://dx.doi.org/10.5539/ies.v5n5p218

\begin{abstract}
With advancement in information technology in the $21^{\text {st }}$ century, e-learning has become an invaluable technology for teaching, learning and research in education. E-learning involves the use of technology to enhance learning including digital collaboration, satellite broadcasting, CD-ROMS amongst others. E-learning has so many advantages over the traditional method of teaching and learning. Besides, so many e-learning tools are available for teaching and learning. However, despite these numerous advantages, a careful look at Nigerian educational system shows that the use of e-learning is still rather slow or imaginary. One of the reasons for this may be due to ignorance, negative perceptions amongst students and teachers and; non-availability of e-learning facilities in the system. This paper critically examined the potentials and immense benefits of e-learning in education generally and business education in particular. The paper also looked into the Nigeria policy on information and communication technology (ICT) as it relates to education. It further presented various methods that may be employed in delivery business education lessons via e-learning. Recommendations were made that there should be awareness creation about the potentials and prospects of e-learning in Nigerian schools amongst others.
\end{abstract}

Keywords: E-learning, study tool, business education

\section{Introduction}

Web-based educational learning system is receiving more and more attention in this era of information and communication technology due to explosive expansion of the World Wide Web and internet. The internet's magnitude is thousands of times what it was only two decades ago. It is estimated that about 60 million host computers are on the internet today while it serves about 200 million users in over 200 countries and territories. However, there is doubt as to whether students and teachers of business education in Nigerian institutions of higher learning are actually responsive to and also fully utilize the immense potentials of the e-learning for academic works. According to Manir (2007), many teachers and students (business education inclusive) are not fully aware of and do not fully utilize the immense potentials of the internet for academic work in the developing countries as compared with the advanced nations of the world with the consequence that paper/printing technologies and face to face discussions and paper resources still dominate our educational system. Manir further stressed that in spite of the Internet and e-learning technologies, there is the challenge of many students and teachers continually depending on traditional ways of doing research though it is very clear that institutions of learning and libraries lack current materials. Even when these materials are available, they are difficult to access due to poor records management systems. These challenges present themselves at a time of increasing students' population, scarcity of learning resources and competitive admission. E-learning as a good substitute may help to reduce if not totally eliminate, the aforementioned barriers usually associated with traditional teaching/learning methods in business education with its numerous potentials and benefits.

In a study by Nafukho (2007) on the place of e-learning in Africa's institutions of higher learning, the results of the study showed that e-learning has a future in Africa's universities and that there is need to build e-learning programmes based on genuine partnerships from other successful partners within and without Africa.

Also, in the study by Greg Wang; Robert Von Der Linn; Diane Foucar-Szocki; Oris Griffin; Erin Sceiford (2003) on measuring the business impact of e-learning, the result showed that e-learning, as a means of technology-based HRD intervention, can be highly effective as a performance support learning mechanism, 
although the results also suggested that e-learning alone is not sufficient to replace the traditional face-to-face learning platforms.

The study by (Strother, 2002) on an assessment of the effectiveness of e-learning in Corporate Training Programs showed that corporate managers are constantly looking for more cost-effective ways to deliver training to their employees. E-learning is less expensive than traditional classroom instruction. In addition, many expenses - booking training facilities, travel costs for employees or trainers, plus employees time away from the job - are greatly reduced. However, it was observed that some firms that have spent large amounts of money on new e-learning efforts have not received the desired economic advantages.

Similarly, Fong-Ling, Hung-Gi and Sheng-Chin (2007) opined that the purpose and characteristics of e-learning are different from other Web applications. Their paper used an extended Technology Acceptance Model (TAM) to explain the motivation, attitude and acceptance behind participants of e-learning. According to the study, the factors that determine Web quality include the external variables: system functionality, interface design, pedagogic and contents, as well as community. Perceived enjoyment was also added to this model as a factor. The empirical results indicated that the extended TAM explains the acceptability of on-line learning systems with high reliability, validity, and model fitness. All "beliefs" (user perceptions)- perceived usefulness, ease of use, and enjoyment- are good predictors of attitude and acceptance. Pedagogic, and content as well as community are important external factors that predict e-learning acceptance.

In spite of the various advantages e-learning has over the traditional approach to teaching, learning and research, the diffusion of e-learning is rather slow (Dhume, Gondkar, Murgaiah, and Subhas, 2006). One of the reasons for this, according to them is the lack of information, negative perception among students and non-availability of e-learning facilities. However, proponents of this technology are of the view that e-learning is as effective as traditional teaching and therefore, offers a good substitute to traditional teaching-learning. Similarly, Bassey, Umoren, Akuegwu and Ntukidem (2007) commented that students' learning in tertiary institutions all over the world has undergone tremendous transformation, especially since the advent of information and communication technology (ICT).

A search in literature revealed paucity of studies on e-learning as a potent tool in vocational business education in Nigerian schools. Even though there is lot of literature on e-learning generally, none has direct input on business education. It is this gap this study seeks to cover. Consequently, the paper extensively reviewed the concept of e-learning, e-learning tools that are suitable for teaching/learning in business education, methods that may be employed in e-business education and their benefits.

\section{The E-learning Concept}

E-learning involves the use of technology to enhance learning including digital collaboration, satellite broadcasting, CDROMS, video and audio conferencing, mobile technology, interactive TV and web based technologies (Bennink, 2004). According to Bennink, many successes in outcomes of learning have been recorded as a result of combination of e-learning with face to face delivery. In the same vein, Eklund, Kay and Lynch (2003) noted that e-learning as a component of flexible learning is a wide set of applications and processes, which use all available electronic media to deliver education and training. It provides people with a flexible and personalized way to learn. It offers learning-on-demand opportunities and reduces learning cost. According to them, e-learning is individual, customized learning that allows learners to choose and review material at their own pace. They further opined that e-learning may be delivered via numerous electronic media, including the Internet, intranets, extranets, satellite broadcast, audio/videotape, interactive television, and CD-ROM. It is not confined to online learning but it includes computer-based learning, web-based learning, virtual classrooms and digital collaboration.

Olaniyi (2006) opined that e-learning is all about learning that occurs at the computer. According to him, the convergence of the Internet and learning, or Internet-enabled learning is called e-learning. The uses of network technologies to create, foster, deliver, and facilitate learning, anytime and anywhere. It is also the delivery of individualized, comprehensive, dynamic learning content in real time, aiding the development of communities of knowledge, linking learners and practitioners with experts. In the opinion of Pinto, Selvaggi, Sicignano, Vollono, Iervolino, Amato, Molinari and Grassi (2008), e-learning is an abbreviation of electronic learning, indicating the provision of education and training on the Internet or the World Wide Web. They noted that the Internet offers numerous advantages compared with other mass media: it provides access to a large amount of information previously known only to individual specialists; it is flexible, permitting the use of images or video; and it allows linking to Web sites on a specific subject, thus contributing to further expand knowledge. 


\section{Nigeria Policy on Information and Communication Technology (ICT)}

Nigeria started implementing its ICT policy in April 2001 after the Federal Executive Council approved it by establishing the National Information Technology Development Agency (NITDA), and the implementing body (Agyeman,2007). In 2003, Microsoft and the Nigerian government signed a three-year agreement intended to enable Nigeria to deploy ICTs in order to accelerate economic growth. This partnership was to help Nigeria build its software development industry as well as streamline the government's use of Microsoft software tools. It was also intended to stimulate the private sector and increase Nigeria's global competitiveness. The Nigerian National Policy on Information and Communication Technology (FRN, 2001) has within its purview the vision, mission, general objectives and strategies for the implementation of the policy, and sectoral application for all sectors (health, agriculture, tourism, education amongst others) was also embedded (Yusuf, 2007). Accordingly, the policy in the areas of education, envisaged the development of ICT curricula for all levels of Nigerian education, the facilities, and ICT dedicated institutions. Some of the objectives of Nigeria's ICT policy according to Yusuf are:

- To ensure that ICT resources are readily available to promote efficient national development.

- To guarantee that the country benefits maximally, and contributes meaningfully, by providing the global solutions to the challenges of the Information Age.

- To empower Nigerians to participate in software and ICT development.

- To encourage local production and manufacture of ICT components in a competitive manner.

- To establish and develop ICT infrastructure and maximize its use nationwide.

- To empower the youth with ICT skills and prepare them for global competitiveness.

- To integrate ICT into the mainstream of education and training.

These are laudable objectives but realizing them has not been easy due to attitudinal, inertia and corrupt tendencies inherent in government implementation policies.

\section{The Present Status of Business Education in Nigeria}

Business education is an educational process or context, which has the primary aim of preparing people for roles in enterprises; such roles could be as employees, entrepreneurs, employers or simply as self-employed persons (Anao, 1986). In Nigeria, business education is offered at the junior secondary, secondary and post-secondary school levels. At the junior secondary school level, it comprises business studies as a pre-vocational subject. At this level, it serves as an introduction to the social sciences subjects and helps students to develop manipulative skills, inventiveness and respect for dignity of labor as well as preparing students for further studies and develops in them the understanding and attitudes needed for successful advancement in their educational pursuit (Epumepu, 2012). At the secondary and post secondary levels, its educational subjects include book keeping, keyboarding, marketing, accounting, office education, office management, store-keeping, co-operative education and desk top publishing/word processing as enshrined in the National Policy on Education (2004).

Preparation of workers for entry into and advancement into the workplace of the next decade requires an educational programme that provides not only job skills, as vocational and technical education is currently doing under the traditional teaching/learning method, but also higher order thinking, problem solving, and collaborative work skills (Doolittle and Camp, 1999). Particularly, vocational and technical education of which business education is a part is aimed at making individuals that will be well armed with skills and knowledge to enable them secure employment either by establishing a small-scale outfit or by being gainfully employed thereby utilizing their skills (Uko-Aviomoh and Ajuluchi (2008). In the $21^{\text {st }}$ century, the traditional teaching method appears to be falling short of this (Hanley, 1995). The problem of how to effectively structure the classroom to achieve the laudable goals of business education under the traditional method of teaching/learning has become a major concern to both educators and students in the programme in the era of information and communication and globalization. In the opinion of Kwache (2007), the pace of change brought about by new technologies has had a significant effect on the way people live, work, and play worldwide while education not exempted. This is the reason while new and emerging technologies are challenging the traditional process of teaching and learning, and the way education is managed. Globally, there is a paradigm shift from the traditional approach of teacher-centered learning to modern methods where ICT plays a significant role hence business education cannot be exempted. ICT has a great speed of providing flexibility, improvement in quality and quantity of learning instead of total dependence on textbooks and materials in prints as teaching and learning in business education has done in the past. The advantages of using the e-learning technology as an education tool 
ranges from capacity of students to personally learn needed skills and information almost in any field imaginable. Through e-learning, students of business education would be able to communicate, collaborate and cooperate with other learners worldwide and assess worldwide libraries irrespective of their place of domicile and bring to fulfillment the goal of business education as enshrined in the National Policy on Education (2004). In the context of teachers' development e-learning can be used for both initial and continuing development through courses, workshops, and other activities, formal and informal, where students and practicing teachers learn about integrating ICTs across curriculum to support learning (Yusufu, 2007).

\section{Delivery of Business Education Lessons via E-learning}

Since 1999, advancement of e-learning has taken different forms. Much of current experience is based on the use of web-based modules which are accessed at an individual's personal computer (Claudia and Popa, 2008). There are so many examples of current e-learning practices. A critical examination of some of these e-learning practices revealed that they could be applied in vocational business education as follow:

- Computer-Based Training (CBT): Computer-based training (CBT) is any course of instruction whose primary means of delivery is a computer. A CBT courseware may be delivered via a software product installed on a single computer, through a corporate or educational intranet, in this case, the teacher does not need internet or website. All that is needed is a computer, a projector, scanner and multimedia objects such as audio, video and speakers for the transmission of learning contents or it could be delivered over the Internet as Web-based training. CBT can be used to teach business education because it is especially good for keyboarding, word processing, information management, business mathematics amongst other subjects. Students can also take advantage of CBT to learn how to run computer applications, such as Microsoft Excel, MS-word, Power point and other Office packages that are related to their field of study.

- Web-based Training: Web-based training (WBT) is an innovative approach to distance learning in which computer-based training (CBT) is transformed by the technologies and methodologies of the World Wide Web, the Internet, and intranets (Kilby, 2009). Web-based training could be used to present business education contents live and in a structure promoting self-directed and self-paced instruction on any topic at any distance. WBT could also be used in the provision of remedial lessons to students. The teacher can also use it for evaluation and assessment of the students objectively.

- Collaborative Learning: Collaborative Learning is online learning, based on interaction with others learners/instructors (Siadaty and Taghiyareh, 2008). E-learning particularly gives room for collaborative and students'-centered learning. When using e-learning technology in business education, all the teacher does is to guide the learners in a virtual classroom environment, through interactive online learning, such as shared whiteboards, shared application software, chat functionality and audio/video over the network. Meanwhile, Brown (1998) noted that there are three ways in which e-learning technology facilitates learning principles: through self-directed learning, through collaborative learning, and through critical analysis.

- Informal E-learning: E-learning can also help to facilitate informal learning in business education. Through internet and e-learning, the business education students can learn outside the course based materials, traditional classroom and can learn about other important things that affect their lives. Students also have the opportunity to learn during holidays and vacations without necessary being taught by his teacher. Martinez (2003) noted that incorporating technology like e-learning into education may provide students with experience that would otherwise not be available to them. For example, computer simulations allow students to discover principles through their own active engagement.

\section{E-learning Tools on the Web Suitable for Business Education}

There are so many e-learning activities and tools on the Web that are suitable for learning in education generally and business education is not exempted. The Australia Commonwealth (2007) enumerated some of these tools. The teacher of business education could do well by considering using them to improve the quality and quantity of teaching and learning. Some of the e-learning tools are under listed:

- $\quad$ eXe: The eXe project is a freely available authoring application to assist teachers and academics in the publishing of web contents without the need to become proficient in HTML or XML mark-up. eXe project is an environment for authoring web-based e-learning content. With the eXe, users can develop learning structures that suit their content delivery needs and build resources that are flexible and easily updated. eXe is an Open Source Software project which is it free to download and use and the source code is also freely available to allow customization to suit the teachers and students needs. Instructions in business education can be transmitted through this mode. 
Flexible Learning Toolboxes: A Toolbox is a collection of high quality resources, suggested learning strategies and supporting material to support online delivery of recognized training packages which could be suitable for learning. They are high quality, cost effective interactive e-learning and assessment resources featuring scenarios, images and activities and support online delivery of recognized training packages for any training imaginable. Toolbox materials come in an integrated learning program incorporating a number of units of competency which are available on a CD-ROM for installation on a server or for use on a stand-alone computer and a learning object format allowing users to download smaller self-contained components of content for free. Use of Flexible Learning Toolboxes in business education could motivate new students into the programme and also help the old ones to learn at their own pace. Teachers and trainers can use Toolbox materials to support traditional classroom delivery or as a learning object to help them deliver learning contents. Learning materials can also be customized to suit different learner's needs and interest at any time.

iLearn: This is a scaleable, open-source e-learning platform with rich functionality for course management, online communities, learning management, and content management. It is an academia platform where students can download learning content such as PDF courseware, laboratory exercises, teaching slides, ISO DVDs. Business education instructors can use iLearn to support their courses or teach an entire class online. On the other hand, they can decide to customize their use of iLearn features by combining it with other learning aids. Business education Instructors who desires to use iLearn can apply it to enhance teaching and learning by sharing online resources, facilitating students interactivity and collaboration or by appraising students performance and getting students feedbacks.

Video Conferencing: Video Conferencing is a collaborative communication tool which allows several individuals or groups to communicate in real time across distances using the data network to transfer packets of learning contents containing audio and video using the voice network. In business education classroom, video conferencing technology could be linked to cameras, computers and whiteboards. It is very suitable for distance and self-paced education. With the use of video conferencing in business education, the barrier of traditional method of learning is removed and this goes a long way to favour the goal of inclusive education. This is possible because video conferencing integrates video and audio to connect users anywhere in the world as if they were in the same classroom.

- YouTube: YouTube is an online public communications site. The site allows for registered users to upload and have available for the public their videos for viewing. In that case, the teachers of business education and students who desire to use YouTube have to register online which is usually free. The teacher thereafter prepares the desired lessons including videos and upload online for the students to read. Anyone who goes to the site can view the lessons and videos that are posted on this site. The students also have the opportunities of having access to other relevant literature worldwide.

- Respondus: Respondus is mainly an assessment tool which the business education teacher can use to assess students learning progress. Respondus is a program that interacts with blackboard, but is basically separate from it. Respondus can be used to compile tests offline, which can then be exported to one or more blackboard courses to be completed online. The teacher can create questions on-line using the Respondus program or he/she can import questions from MS-Word into Respondus and print out test questions. It supports so many question types, including calculated and algorithmic formats. Meanwhile the teacher can choose to import questions from MS-Word or use the Respondus Exam Wizard to create an assessment in minutes amongst other benefits.

- SMART Board interactive whiteboard: An interactive whiteboard is a large interactive display that connects to a computer and projector. This is highly suitable for students' project, presentations and seminars. A projector projects the computer's desktop onto the board's surface where users control the computer using a pen, finger, stylus, or other device. The board is typically mounted to a wall or floor stand. They are used in a variety of settings, including classrooms at all levels of education, in corporate board rooms and work groups. Instructions in business education can be transmitted through this mode.

It is impossible to apply all these packages to business education programme in one setting. They can be adapted to many aspects of the programme depending on the socio-economic, cultural and political setting where the programmes are operated.

\section{Benefits of E-learning in Business Education}

E-learning should be seen as offering solutions to several challenges currently facing higher education (NetTOM, 2007) cited in (Bassey, 2007) business education inclusive. Through e-learning, students of business education would be able to communicate, collaborate and cooperate with other learners worldwide and assess worldwide libraries irrespective of their geographical locations and bring to fulfillment the goal of business education as 
enshrined in the National Policy on Education (2004). According to Sharifabadi (2006) cited in Panda and Swain (2009), e-learning will benefit teaching and learning in the following ways:

- for learners, e-learning knows no time zones, and location and distance are not an issue;

- in asynchronous e-learning, students can access the online materials at any time;

- $\quad$ synchronous e-learning allows for real time interaction between students and instructors;

- e-learners can use the internet to access up-to-date and relevant learning materials, and can communicate with experts in the field in which they are studying;

- $\quad$ situated learning is facilitated, since learners can complete online courses while working on the job or in their own space, and can contextualize the learning;

- online materials can be updated as per the needs of the learners, and learners are able to see the changes at once, and;

- when learners are able to access materials on the internet, it is easier for instructors to direct them to appropriate information based on their needs.

\section{Conclusion}

With the information technological breakthrough in the $21^{\text {st }}$ century, e-learning has become an invaluable technology tool for teaching, learning and research. E-learning involves the use of technology to enhance learning including digital collaboration, satellite broadcasting, CDROMS, video and audio conferencing, mobile technology, interactive TV and web based technologies (Bennink, 2004). E-learning has numerous advantages over the traditional method of teaching/learning. Despite these advantages however, the diffusion of e-Learning in business education is rather slow or imaginary in Nigeria (Dhume, Gondkar, Murgaiah, and Subhas, 2006). One of the reasons for this may be lack of proper information, negative perceptions amongst students and teachers and non-availability of e-learning facilities. This paper is of the opinion that adequate awareness about the potentials of e-learning in education and availability of facilities could motivate the students and teachers of business education to adapt to the more efficient and effective use of e-learning. The paper therefore, recommended that there should be awareness creation about the potentials and prospects of e-learning in education generally and business education in particular amongst others.

\section{Recommendations}

Based on the study the following recommendations are made;

- There should be awareness creation about the potentials and prospects of e-learning in Nigerian institutions of higher learning.

- There should be short training courses for both teachers and students on e-learning use, methods and procedures in business education.

- Computer laboratories with internet facilities should be provided for all business education departments in universities, polytechnics and colleges of education in Nigeria.

- Alternative power supply should be made available in the departments of business education in all schools to ensure constant power supply for internet and e-learning services.

\section{References}

Agyeman, O. T. (2007). ICT for Education in Nigeria. Survey of ICT and Education In Africa: Nigeria Country Report. Retrieved October 24, 2010, from www.infodev.org/en/Document.422 pdf

Australian National Training Authority. (2005). Austrialian Flexible Learning Framework. $\begin{array}{lllll}\text { Flexible-learning.net.au. } & \text { Retrieved } \quad \text { October 21, 2010, from }\end{array}$ www.pre2005.flexiblelearning.net.au/.../2003/elearning250903final.pdf

Bassey, U. U., Umoren, G. U., Akuegwu, B. A., Udida, L. A., \& Ntukidem, E. P. (2007). ICT-Learn2007. Presented at the Sixth International Internet Education Conference. Ramses Hilton, Cairo, Egypt.

Bennink R. (2004). Implementing e-learning from the corporate perspective. Retrieved October 1, 2010, from www.knowledgetree.flexiblelearning.net.au/edition05/.../bennink.pdf

Blezu, C., \& Popa, E.M. (2008). E-Learning and its Prospects in Education. 12th WSEAS International Conference on COMPUTERS, (pp. 23-25), Heraklion, Greece. 
Brown, B. L. (1998). How Does Technology Facilitate Constructivist Learning? ERIC Clearinghouse on Adult, Career, and Vocational Education, Information Series No. 378, 1998. In Susan Lucas (2002). All 601: Principles of instructional technology. Retrieved October 10, 2010, from http://susanlucas.com/it/ail601/crit.html

Commonwealth Australia. (2007). E-learning Tools. Retrieved October 1, 2010, from $\mathrm{http}: / /$ trades.flexible-learning.net.au/e-learntools.html

Daniel, S. (1994). Teaching \& Learning with Internet Tools. A Position Paper. Presented at the Workshop on "Teaching \& Learning with the Web" at the First International Conference on the World-Wide Web, 1994 at CERN, Geneva. Retrieved October 11, 2010, from http://tecfa.unige.ch/

Dhume, S., Raju Gondkar, R., Murgaiah, V., M. S., \& Subhas, M. S. (2006). Perceptions of Business Education Students towards e-learning: An Empirical Study of North Karnataka region of India. Presented by the Commonwealth of Learning and the Caribbean Consortium. Retrieved October 1, 2010, from http://pcf4.dec.uwi.edu/viewabstract.php?id=168

Doolittle, P. E., \& Camp, W. G. (1999). Constructivism: The Career and Technical Education Perspective. Journal of Vocational and Technical Education, 16(1), Retrieved October 21, 2010, from http://scholar.lib.vt.edu/ejournals/JVTE/v16n1/doolittle.html

Eklund, J., Kay, M., \& Lynch, H. M. (2003). E-learning emerging issues and key trends. Retrieved October 21, 2010, from http://pre2005.flexiblelearning.net.au/research/2003/elearning250903final.pdf

Epumepu, E. A. (2012). A comparison of students' academic performance in business studies in Junior Secondary School Certificate Examinations (JSSCE) in Public and Private schools in Ovia South West L.G.A., Edo State. M.Ed. project proposal submitted to the Department of Vocational and Technical Education, Faculty of Education, University of Benin, Benin City.

Fong-Ling, F., Hung-Gi, C., \& Sheng-Chin Y. (2007). Activate Interaction Relationships Between Students Acceptance Behavior and E-Learning. Advances in Data and Web Management. Lecture Notes in Computer Science, 4505, 670-677. http://dx.doi.org/10.1007/978-3-540-72524-4_69

Gunawardana, K. D. (2005). An Empirical Study of potential challenges and Benefits of Implementing E-learning in Sri Lanka. Proceedings of the Second International Conference on e-learning for Knowledge-Based Society, August, pp. 4-7.

Hanley, S. (1994). On Constructivism. Maryland Collaborative for Teacher Preparation. Retrieved October 1, 2010, from http://www.inform.umd.edu/UMS+state/UMD-Projects/MCTP/Essays/Constructivism.txt.

Kilby, T. (2009). What is Web-Based Training? (@ 1994-2009) Tim Kilby. Retrieved October 11, 2010 from http://www.webbasedtraining.com/primer_whatiswbt.aspx

Kwache, P. Z. (2007). The Imperatives of Information and Communication Technology for Teachers in Nigeria Higher Education. MERLOT Journal of Online Learning and Teaching, 3(4).

Martinez, M. (2003). Technology \& Education. Research Paper. ELPS 420. Retrieved October 26, 2010 from http://orion.it.luc.edu/ mmart13/graduate/Content/techphilosophy420.doc

Mugarura, C. (2010). Strategies for Deploying e-learning in developing Countries. Retrieved October 14, 2010 from http://edutechdebate.org/e-learning-promise/strategies-for-deploying-e-learning-in-developing-countries/

Nafukho, F. M. (2007). The place of E-learning in Africa's institutions of higher learning. Higher Education Policy, 20, 19-43. http://dx.doi.org/10.1057/palgrave.hep.8300141

Olaniyi, S. S. (2006). E-Learning Technology: The Nigeria experience shape the change. XXIII FIG Congress. Munich Germany.

Pinto, A., Selvaggi, S., Sicignano, G., Vollono, E., Iervolino, L., Amato, F., Molinari, A., \& Grassi R. (2008). E-learning tools for education: regulatory aspects, current applications in radiology and future prospects. National Center for Biotechnology Information, U.S. National Library of Medicine 8600 Rockville Pike, Bethesda MD, 20894 USA 
Schneider, D. (1994). Teaching \& Learning with Internet Tools. A Position Paper presented at the Workshop on "Teaching \& Learning with the Web" at the First International Conference on the World-Wide Web, 1994 at CERN, Geneva.

Sharifabadi, S. R. (2006). How digital libraries can support e-learning. The Electronic Library, 24(3), 389-401 cited in Panda, B. P. and Swain, D. K. (2009). Effective Communications through e-Governance and e-Learning. Chinese Librarianship: an International Electronic Journal, 27. Retrieved October 1, 2010, from http://www.iclc.us/cliej/cl27PS.htm

Siadaty, M., \& Taghiyareh, F. (2008). E-Learning: From A Pedagogical Perspective. International Journal of Information Science \& Technology, 6(2), 100-107.

Strother, J. B. (2002). on An Assessment of the Effectiveness of e-learning in Corporate Training Programs. The International Review of Research in Open and Distance Learning, 3(1). Retrieved October 20, 2010, from http://www.irrodl.org/index.php/irrodl/article/viewArticle/83/160

Wang, G., Robert Von, D. L., Foucar-Szocki, D., Griffin, O., \& Sceiford, E. (2003). Measuring The Business Impact of E-Learning: An Empirical Study. Performance Improvement Quarterly, 16(3), 17-30. http://dx.doi.org/10.1111/j.1937-8327.2003.tb00285.x

Yusuf, M. O. (2007). Trends and Barriers on the Integration of Information and Communication Technology in the Nigerian School System. Accepted for publication in Studies in Curriculum, 2007, Department of Curriculum Studies and Instructional Technology, Olabisi Onabanjo University, Ago Iwoye, Nigeria. 